https://helda.helsinki.fi

\title{
A discrete time model for succession of ground cover communities after clear cutting.
}

Kauppi, P.E.

Blackwell

1978

Kauppi, P.E., Hari, P. and Kellomäki, S. 1978. A discrete time model for succession of ground cover communities after clear cutting. Oikos 30: 100-105.

http://hdl.handle.net/1975/404

Downloaded from Helda, University of Helsinki institutional repository.

This is an electronic reprint of the original article.

This reprint may differ from the original in pagination and typographic detail.

Please cite the original version. 


\title{
A discrete time model for succession of ground cover communities after clear cutting
}

\author{
Pekka Kauppi, Pertti Hari, Seppo Kellomäki \\ Department of Silviculture, University of Helsinki
}

Kauppi, P., Hari, P. and Kellomäki, S. 1978. A discrete time model for succession of ground cover communities after clear cutting. - Oikos 30: 100-105.

A model for succession of ground cover communities based on the difference in time
of occurence of different plant species in succession has been developed. Plant spe-
cics have been divided into pioneer, intermediate and climax species assuming that
climax species can supersede pioneer species in competition for resources. By apply-
ing matrix notations the model can be presented in quite a simple form. The para-
meters of the model were estimated, and the coursc of succession has becn computed
for a ground cover community following clear cutting.

P. Kauppi, P. Hari and S. Kellomäki, Dept of Silviculture, Unioninkatu 40 B, SF-00170 IIelsinki 17, Finland.

\begin{abstract}
Ғыла ралработана моцель сукцессии растительного покрона, фозданная на

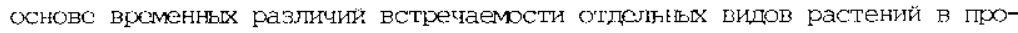
цессе сукцессии. Випы растсний были разделены на пионерные, промюжуточнце и климаксонеле, причсм предполагалось, что поспедние могут вытеснять пионерные в процессе конкуренции за пиденье рссурсы. При применении матриц модель может бить изображеца в очснь простой форме. Лана оценка параметров модели; процесс сукцессии гроаналиэирован дыя растительньх сообцсстн, развиванщихся на месте сплапой ныругки.
\end{abstract}




\section{Introduction}

The concept of succession is used in order to describe a serics of directional changes in community structure. The successional community can be divided into several stages. In particular, the concepts of pionecr and climax stages have been applied frequently for describing the differences between plant communities occupying the same site during early and late succession (Clements 1963: 72-78, Mueller-Dombois and Ellenberg 1974: 380-397). The community members are called pionecr or climax species, respectively. Thus plant species have been divided into different categories according to the stage at which they occur during community development. The present classification is crude, but it does make it possible, however, to give a general description of community development during the course of succession. On the other hand, this approach enables further consideration to be made of the mechanisms involved in succession and its modelling.

The aim of the present paper is to develop a descriptive model for community development in the course of succession based on the different competitional power of the different species catcgories. The model has been applied to the ground cover of a tree stand after clear cutting.

\section{Study approach}

The presence of a plant species in a successional community is dependent on its competitional power (cf. Clements 1963: 72-78). The process of succession is rather regular within the limits set by the environment and therefore the time occurrence for each species can be recognized. In practice, however, it is possible to distinguish only a few catcgories, such as pioneer and climax species. In addition to these two categories, a category for intermediate species is introduced, i.c. for species which occur in the intermediate stage of succession.

Let $\mathrm{x}_{\mathrm{In}}$ denote the non-occupied area in the year $\mathrm{n}$, $x_{2 n}$ the area occupied by pioneer species, $x_{3 n}$ the area by intermediate species and $\mathrm{x}_{4 \mathrm{n}}$ the arca by climax species, correspondingly. The reoccupation ratio $\mathrm{a}_{\mathrm{ij}}$ is defined as the ratio between the area vacated by spccies class $i$ from the species class $j$ and the area of species class $j$. Thus the area reoccupied by species $i$ from species $j$ is $a_{i j} \cdot x_{j n-1}$.

The climax species can increase its area at the expense of the other species. This can be formulated as follows

$\mathrm{x}_{4 \mathrm{n}}=\mathrm{a}_{41} \mathrm{x}_{1 \mathrm{n}-1}+\mathrm{a}_{42} \mathrm{x}_{2 \mathrm{n}-1}+\mathrm{a}_{43} \mathrm{x}_{3 \mathrm{n}-1}+\mathrm{x}_{4 \mathrm{n}-1}$.

The intermediate specics can increase its area at the expense of non-occupied areas and pioneer species classes and lose it to climax species

$x_{3 n}=a_{31} x_{1 n-1}+a_{32} x_{2 n-1}+x_{3 n-1}-a_{43} x_{3 n-1}$.
The pioneer species can increase their coverage at the expense of non-occupied areas and lose it to intermediate and climax species

$x_{2 n}=a_{21} x_{1 n-1}+x_{2 n-1}-a_{32} x_{2 n-1}-a_{42} x_{2 n-1}$.

The non-occupied area can only decrease

$x_{1 n}=x_{1 n-1}-a_{2,} x_{1 n-1}-a_{31} x_{1 n-1}-a_{41} x_{1 n-1}$.

Injury to the plant species is now described by four equations which include six parameters. These equations are recursive i.e. the situation for one year is calculated with the help of the situation the previous year. These equations are now rather complicated. Their formalization can be simplified by using matrix notations.

Let us define the state vector $X_{n}$ as

$$
X_{n}=\left[\begin{array}{l}
x_{1 n} \\
x_{2 n} \\
x_{3 n} \\
x_{4 n}
\end{array}\right]
$$

The reoccupation matrix $A$ is defined

$A=\left[\begin{array}{cccr}1-a_{41}-a_{31}-a_{21} & 0 & 0 & 0 \\ a_{21} & 1-a_{32}-a_{42} & 0 & 0 \\ a_{31} & a_{32} & 1-a_{43} & 0 \\ a_{41} & a_{42} & a_{43} & 1\end{array}\right]$

The Eqs (1)-(4) can now be written in condensed form

$\mathrm{X}_{\mathrm{n}}=\mathrm{A} \mathrm{X_{ \textrm {n } - 1 }}$

The state vector $\mathrm{X}_{\mathrm{n}-1}$ can be expressed using the previous year and so on

$X_{n}=A \cdot X_{n-1}=A \cdot A X_{n-2}=A \cdot A \cdot A \cdot X_{n-3}=$
$=\ldots=A^{n} X_{0}$

Thus the state vector $X_{n}$ can be computed from Eq. (8), if the initial state vector $\mathrm{X}_{0}$ and the reoccupation matrix is known. This model is analogous with that presented by Pielou (1969) for growth of an animal population with age-dependent birth and death rates and by Horn (1976) for tree strata of a stand.

\section{Material}

In order to estimate the parameters of Eq. (8) the material for ground cover communitics of the Myrtillus site type (cf. Cajander 1949) collected during the third inventory of Finnish forests in 1951-1953 was utilized. For this purpose several inventory transects werc selected representing south boreal vegetation in central Finland (Fig. 1). The sample plots were selected in such a way that they represent a successional series of one hundred years. The description of ground cover was carried out by applying the concept of coverage. In this procedure vascular plants, field layer, and bryophytes, bottom layer, were treated separately, as has also been 


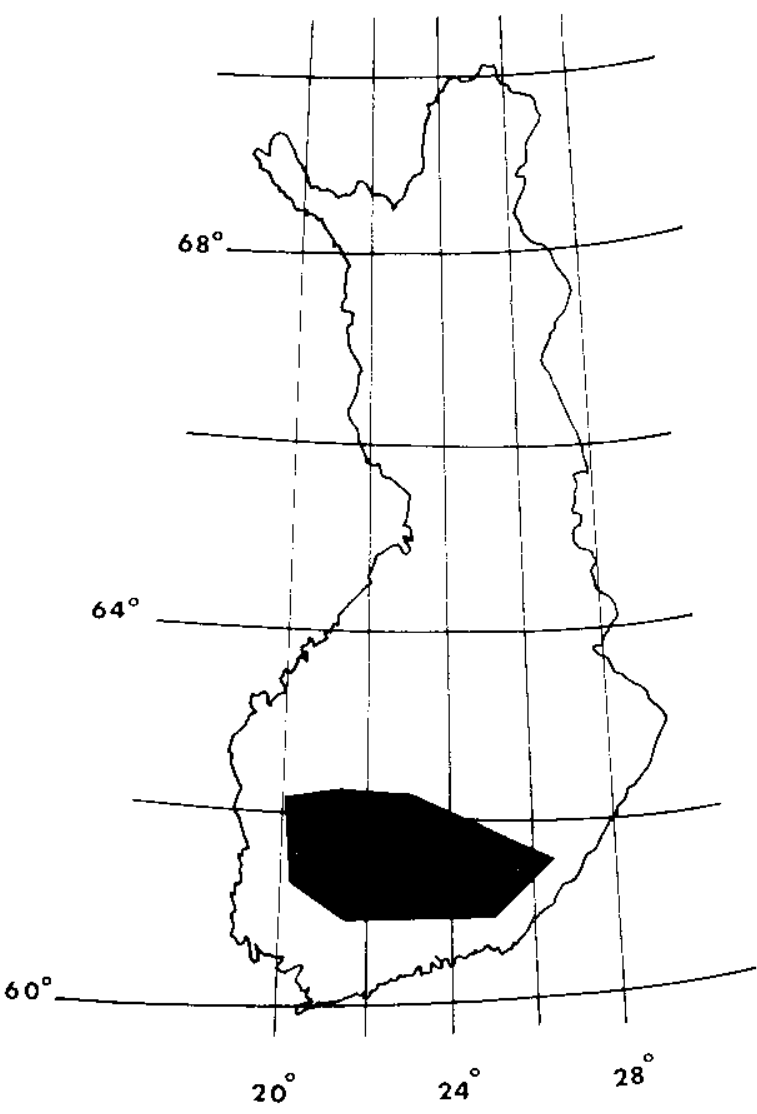

Fig. 1. Region of data collection

done in the analysis. Tree strata and brush layer were excluded from the material owing to the changes in their structure caused by silvicultural measures. A detailed description concerning the methods applied in the description of ground cover is given by Kujala (1964).

The plant species of the ground cover were divided into pioneer, intermediate and climax species. In particular, the studies by Kujala (1926a, b) concerning the ecological properties of different plant species were applied in classification. The classification of plant species is presented in Tab. 1.

\section{Results}

The six parameters of Eq. (8) were estimated using the method of least squares applying computer interation. The numerical values of the parameters are presented in Tab. 2. At the second step of the analysis a computation for the share of different categories during the course of succession was carried out applying the above mentioned parameters. The results of these computations for the field layer and bottom layer are presented in Fig. 2 .

\section{Discussion}

The present model is based on the assumption that the competitive power of each successional category does not change during the course of succession. According to this assumption development of the community approaches a steady state where the abundance of the different species remains unchanged and the community structure is characterized by climax species with patchy and tow occurrence of other successional categories. Owing to the computational procedure the proportional relations between species' abundances in stationary composition are independent of the initial composition of the plant community and are only determined by the matrix of competitive power of successional categories. Thus, the events taking place in the environment before the appearance of the initial community have no effects on the course of community development determined by matrix of competitive power (cf. Horn 1976).

The present model is compiled in such a way that pioncer species are suppressed by intermediate species and climax species and intermediate species by climax species, i.e. hierarchically. Owing to the reproductive strategy of vascular plants in the ground cover such successional processes in the field layer are evident. Due to the clonal distribution of plant species it is ordinary that plant species belonging to other successional categories than pioneer species appear in early successional stages, and hence the hierarehical occupation of a site is pos-
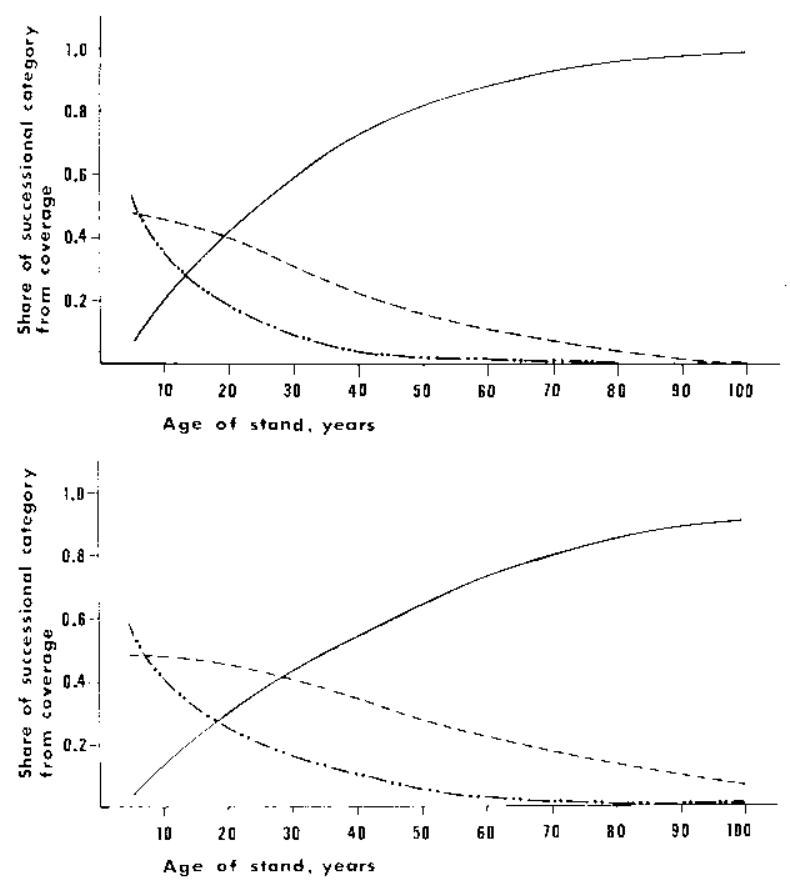

Fig. 2. Above: Course of succession for the field layer. Solid line represents climax species, broken line represents intermediate species, and chained line represents pioneer species. Below: Same as above but for the bottom layer. 
Tab. 1 A. Plant species of the field layer belonging to different successional categories.

\begin{tabular}{|c|c|c|}
\hline Pionect & intermediate & climax \\
\hline 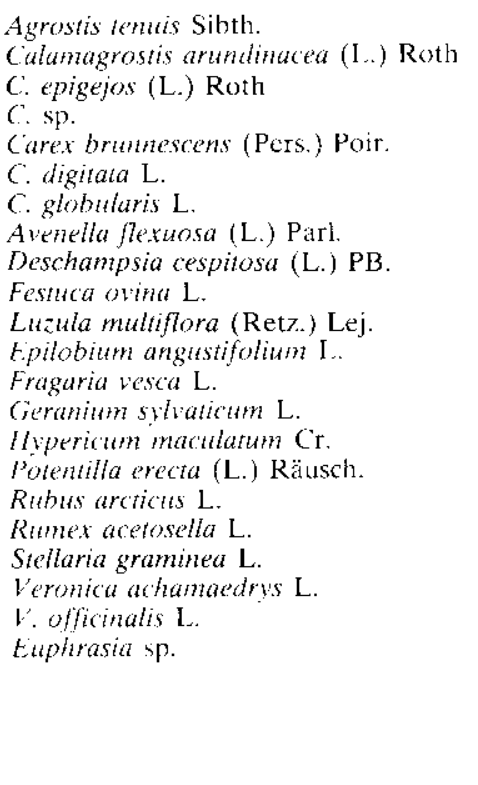 & 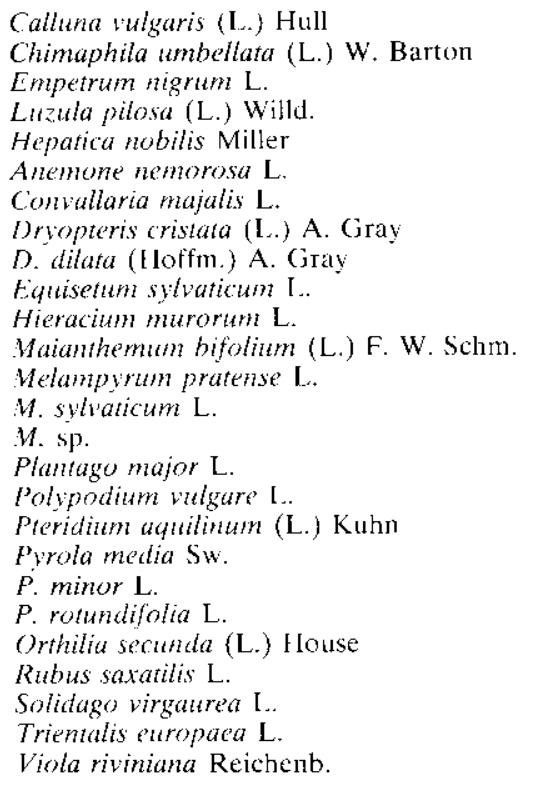 & 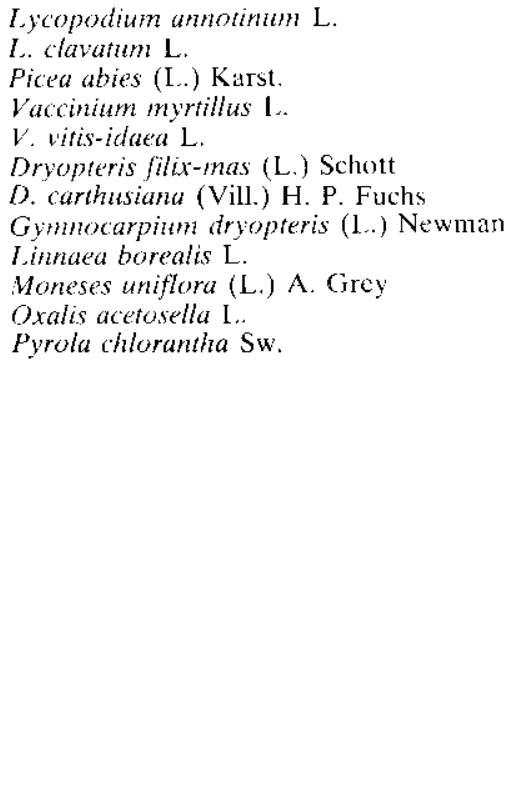 \\
\hline
\end{tabular}

B. Plant species of the bottom layer belonging to different successional categories.

\begin{tabular}{|c|c|c|}
\hline Pioneer & Intermediate & Climax \\
\hline $\begin{array}{l}\text { Polytrichum juniperimm Hedw. } \\
\text { Cetraria islandica (L.) Ach. } \\
\text { Cladonia arbuscula(Wallr.) Rabents. } \\
\text { C. fimbriata (l.) Sandst. }\end{array}$ & $\begin{array}{l}\text { Aulacomniam palustre (Hedw.) Schwacgr. } \\
\text { Brachytecium curtum (Lindb.) C. Jens. } \\
\text { Polytricham commune Hedw. } \\
\text { Rhodobryum rose'tm (Hedw.) Limpr. } \\
\text { Rhytidiadelphus triquetrus (lledw.) Warnst } \\
\text { Sphagnum girgensohnii Russ. } \\
\text { Peltigera aphhosa (L.) Willd. } \\
\text { P. malacea (Ach.) Funck }\end{array}$ & $\begin{array}{l}\text { Dicranum elatum I indb. } \\
\text { D. majus Sm. } \\
\text { D. plysetum Sw. } \\
\text { Hylocomium splendens (Hedw.) B.S.G. } \\
\text { Pleurozium schreberi (Brid.) Mitt. } \\
\text { Ptilium crista-castrensis (Hedw.) DeNot. } \\
\text { Nephroma arcticum (L.) Torss. }\end{array}$ \\
\hline
\end{tabular}

Tab. 2A. Conpetitive power of different successional categories in the field layer.

\begin{tabular}{|c|c|c|c|c|}
\hline \multirow{2}{*}{$\begin{array}{c}\text { Successional category } \\
\text { increasing }\end{array}$} & \multicolumn{3}{|c|}{$\begin{array}{c}\text { Successional category } \\
\text { decreasing }\end{array}$} & \\
\hline & 1 & 2 & 3 & 4 \\
\hline \multicolumn{5}{|c|}{ Bare ground .......... (J) } \\
\hline \multicolumn{5}{|c|}{ Pioneer species ........(2) 1.0000} \\
\hline Intermediate species ....(3) & 0.6620 & 0.0 .425 & & \\
\hline Climax species.........(4) & 0.0000 & 0.0000 & 0.0312 & \\
\hline
\end{tabular}

B. Competitive power of different successional categories in the bottom layer.

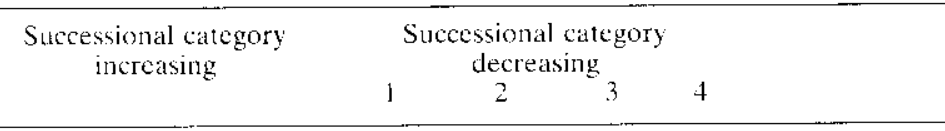

\footnotetext{
Bare ground $\ldots \ldots \ldots$ (1)

Pioneer species ..........(2) 1.00000

Intermediate species $\ldots . .(3) 0.5870 \quad 0.0612$

Climax species..........(4) $0.00000 .0000 \quad 0.0500$
} 
sible, as argued by Witford (1949) and Oinonen (1968, 1971). In the bottom layer, i.e. among the mosses and lichens, hierarchical succession is not absolutely necessary. It is reasonable to assume that plant species invade the bottom layer communities one after another in such a way that early successional species make the site suitable for late successional species as suggested by Clements (1963). However, it is evident that hierarchical succession is the main process of succession among vascular plants as a result of vegetative reproduction which is favoured in natural selection as regarded adaptation to decreasing resources of the developing community as argued by Horn (1976).

The present method gives no answer to the question regarding the mechanisms involved in competitive hierarchy. According to Horn (1971) the most probable reasons for differences in successional status between plant species are found in the relationship between growth rate and light conditions of different plant species. In particular, differences arc caused by the distribution of leaf mass in growth volume, and species with multi-layer leaf distribution seem to be superior to species with monolayer leaf distribution in great light intensities, and mono-layer species are adapted to low light intensities. Horn (1971) supposes that differences in plant species' photosynthetic responses to varying light intensities are, however, not sufficient to explain successional processes, but the constitutional differences in photosynthetic activity seem to be compensated by the distributional pattern of assimilates to shoot and root systems. Schultze (1972) agrecs with the latter assumption, and demonstrates that high encrgy investment primarily above ground with the establishment of new leaves gives a plant species a high competitive potential (cf. also Licth and Aston 1961). As regards the adaptive strategy of plant species it may be meaningful that early successional species grow quickly but cannot survive in suppressed conditions as can dominates of the late successional stages (ci. Horn 1976).

The present model is constructed from four successional categories but generalizing for a larger number of catcgorics does not involve much trouble. In theory, the model can be computed using one specics but great practical problems are encounted in determining the successional status of each species as regards ground cover. In this respect the tree stratum is not so complicated and a more precise application of the present model could be possible as suggested by Horn's (1976) formulations for trec stratum based on demographic characteristics of tree stratum.

Predictions for the course of succession of field and bottom layers were also carried out. The results show that the dominance of grasses and herbs in early succession changes to the dominance of dwarf shrubs and mosses as community development is taking place, as expected. This result is only to be expected and is dependent on the classification applied in formation of successional categories but it does agree with the pre- sent knowledge concerning the successional status of members of ground cover communities in Finnish conditions (cf. Kujala 1926a, b). Applying matrix notations the ideas have been operationalized in order to allow quantitative analysis. What is evidently more problematic is the quality of the material since it includes unspecified variation caused by the general approach, i.c. the present successional series is compiled by the stands representing cross scctions of different successional series. The monitoring of permanent plots would provide much better facilities for the analysis of the present problem than the available material. However, this fact does not decrease the reliability of the results to any great extent as discussed earlier.

Acknowledgements - It is our pleasure to acknowledge prof. $\mathrm{P}$. Yli-Vakkuri, Head of the Dept of Silviculture of University of Helsinki, for his supporting attitude to the present study. Prof. K. Kuusela and T. Kallio of the Finnish Forest Research Institute have kindly provided the data collected in III inventory of Finnish forests. The authors also express appreciation 'for assistance in classifying the plant species to $\mathrm{Dr} \mathrm{T}$. Koponen. Financial support was given by the Academy of Finland.

\section{References}

Cajander, A. K. 1949. Forest types and their significance.Acta For. Fenn. 56.

Clements, F. C. 1963. Plant succession and indicators. A definitive edition of plant succession and plant indicators. Hafner Publishing Co., New York.

Horn, H. 1971. The adaptive geometry of trees. Monographs in population biology 3. - Princeton University Press. Princeton.

- 1976. Successions. - In: May, R. M. (ed.), Theoretical ccology. Principles and application, pp. 187-204. Blackwell Scientific Publications, Oxford.

Kujala, V. 1926a. Untersuchungen über die Waldvegetation in Süd- und Mittelfinnland I. Zur Kenntnis des ökologisch biologischen Charakters der Waldplanzenarten unter spezieller Berücksichtigung der Bildung von Pflanzenvereinen A. Gefässpflanzen. - Comm. Inst. For. Fenn. 10.

- 1926b. Untersuchungen über die Waldvegetation in Südund Mittelftnnland I. Zur Kenntnis des ökologisch - biologischen Charakters der Waldpflanzenarten unter spezieller Bcrücksichtigung der Bildung von Pflanzenvereinen B. Laubmoose. - Comm. Inst. For. Fenn. 10.

- 1964. Über die Frequenzverhältnisse der Wald- und Moorpflanzen in Finnland. Ergebisse der III. Reichswaldabschätzung 1951-1953. - Comm. Inst. For. Fenn. 59.

Licth, H. and D. H. Ashton. 1961. The light compensation points of some herbaceous plants inside and outside deciduous woods in Germany. - Can. J. Bot. 39: 1255-1259.

Mueller-Dombois, D. and H. Ellenberg. 1974. Aims and methods of vegetation ecology. - John Wiley, New York.

Oinonen, E. 1968. Lycopodium clavatum (L.) ja L. annotinum (L.) kasvustojen laajuus rinnastettuna samanpaikkaisiin $L$. complanatum (L.) ja Pteridium aquilinum (L.) esiintymiin sekä puuston ikään. Summary: The size of Lycopodium clavatum (L.) and $L$. annotinum (L.) stands as compared to that of L. complanatum and Pleridium aquilinum (L.) stands, the age of the tree stand and the dates of fire on the sites. - Acta For. Fenn. 87.

- 1971. The time table of vegetative spreading in oak fern (Carpegynmia dryopteris L.) and maylily (Maianthemum bifolium L.) in Southern Finland. - Acla For. Fenn. 118. 
Piclou, E. C. 1969. An introduction to mathematical ecology. John Wiley, New York.

Schultze, E.-D. 1972. Die Wirkung von Licht und Temperatur auf den $\mathrm{CO}_{2}$-Gaswechsel verschiedener Lebensformen aus der Krautschicht eines montanen Buchwaldes. - Oecologia (Berl.) 9: 235-258.
Witford, P. B. 1949. Distribution of woodland plants in relation to succession and clonal growth. - Ecology 30: 199-208. 